\title{
当院における人工膝関節置換術の中期成績
}

\author{
高地赤十字病院整形外科 \\ 梶 浦 清 司・神 村 盛 裕 \\ 青山茂樹 ·野 並誠二 \\ 笠 井 時 雄
}

\section{Clinical Results of Total Knee Replacement}

by

Kiyoshi Kajiura, Morihiro Kamimura, Shigeki Aoyama

Seiji Nonami and Tokio Kasai

Department of Orthopaedic Surgery, Kochi Red Cross Hospital

We studies 57 knees in 55 patients. 47 knees in 43 had osteoarthritis (OA), and 9 knees in 7 had rheumatoid arthritis (RA). Average age was 71.0 years and the mean follow-up was 3.5 years.

On radiological examination, no cases had a "Clear Zone" of over $2 \mathrm{~mm}$. Six knees (10.5\%) had patella malposition.

Using the criteria described by three universities, clinical score was 83.0 points in $\mathrm{OA}$ and 80.0 points in RA. These successful results may have been due to preoperative traction, $\mathrm{ROM}$ exercise, and exact surgical technique.

は じめに

変形性膝関節症及び慢性関節リウマチに対して, 1980 年 12 月から 1989 年 12 月までに, 人工膝関節置 換術を 50 症例 57 関節に施行した.

今回その術後成績を評価し，X線学的検討を加えて 報告した。

\section{対象と方法}

50 症例 57 関節の全例につき調查を行い，その内訳 は以下に示す通りである.

対象疾患：OA 43 例 48 関節

RA 7 例 9 関節

手術時年齢： $51 \sim 89$ 歳（平均 71 歳）

術後経過期間 : 1 年 8 年 6 ケ月

(平均 3 年 5 ケ月)

使用人工関節 :

Total Condylar Knee 型
Kinematic 型 $\quad 16$

$\mathrm{M} / \mathrm{G}$ 型 27

セラミック型 1 関節

これらの症例に対して, 三大学試案による膝関節機 能の臨床評価と X 線計測による下肢アライメント，コ ンポーネントの設置角度及びコンポーネント周囲の骨 透亮像などの評価を行った。コンポーネントの設置角 度 $\angle \alpha, \beta, \gamma, \delta$ 及び大腿脛骨角 FTA を計測した. 骨透亮像の有無はコンポーネント周囲の各部位につい て確認した。さらに, 膝蓋骨の外側偏位率が $20 \%$ 以 上の症例を検討した.

また， $30^{\circ}$ を超える重度屈曲拘縮例については術前 及び術後の屈曲拘縮角度変化を経時的に測定し検討し た.

\section{結果}

膝関節機能評価（三大学試案）では, OA では総合 点術前平均 54.0 から術後平均 83.0 へ, RA では 35.2 
から 80.0 へと, 共に著しい改善がみられる.内容的 には, 歩行能力・日常動作の改善もあるが, 疼痛の改 善が顕著である（図 1 ).

関節可動性では, OA が平均 Flex. $+5^{\circ}$, Ext. $2^{\circ}$, total $+3^{\circ}$, RA では平均 Flex. $+18^{\circ}$, Ext. $+7^{\circ}$, total $+25^{\circ}$ の改善を認めた. 全体として, OA ではあまり変化はみられないが, RA では, 有意 な可動域の改善があった。

FTA は, OA は術前平均 $185.2^{\circ}$ から術後平均 $178.6^{\circ}$ へ, RA では $176.1^{\circ}$ から $174.9^{\circ}$ へと改善した。

コンポーネントの設置角度は, Kinematic 型と $\mathrm{M} / \mathrm{G}$ 型について検討した. Kinematic 型では， $\angle$ $\alpha$ と $\angle \gamma$ より, 大腿コンポーネントは前額面では $4^{\circ}$ 外反位でほほ良好に設置されているが，矢状面におい ては大腿長軸に対して軽度屈曲位で設置されていた。

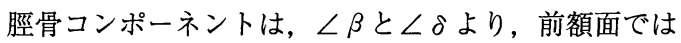
$5{ }^{\circ}$ 内反位で, 矢状面では, 良好に設置されていた。 $\mathrm{M} / \mathrm{G}$ 型では, $\angle \alpha$ と $\angle \gamma$ より, 大腿コンポーネン 卜は前額面では $5.8^{\circ}$ 外反位で, 矢状面でも, 大腿長 軸に対して軽度屈曲位と, 設置は良好であった. $\angle \beta$ と $\angle \delta よ り$, 脛骨コンポーネントも, 前額面で脛骨長 軸に対して垂直に, 矢状面で $10^{\circ}$ 後方傾斜角を持って 良好に設置されていた（表1）。

脛骨コンポーネント周囲の骨透亮像は, Total Condylar Knee 型・Kinematic 型については, 29 関節中 15 関節（51.7\%）に認めた。Clear Zoneは すべて脛骨コンポーネント内側に集中しており，前例 $2 \mathrm{~mm}$ 以下であった． $\mathrm{M} / \mathrm{G}$ 型では， 27 関節中 10 関節（37.0\%）に認めた. Clear Zoneはすべて脛骨 コンポーネント内側に集中していた.

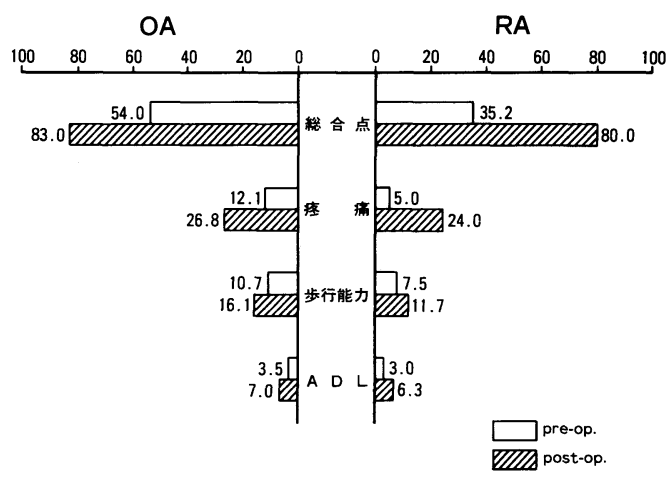

図 1 三大学試案による臨床評価
膝蓋骨外側偏位率が $20 \%$ 以上を示すのは， 5 例 6 関節 $(10.4 \%)$ に認められ Patella Tilt は平均 $11.7^{\circ}$ であった（表 2 )。しかし膝蓋大腿不適合による症状 を訴えるのは， 2 例 2 関節であるが，症状軽度であり， 経過観察中である.

次に, $30^{\circ}$ を超える重度屈曲拘縮例について入院時

表 1 名コンポーネントの設置角度

\begin{tabular}{|l|l|l|l|l|}
\hline Type & $\alpha\left(^{\circ}\right)$ & $\beta\left(^{\circ}\right)$ & $\gamma\left(^{\circ}\right)$ & $\delta\left(^{\circ}\right)$ \\
\hline Kinematic & 94.0 & 85.0 & 84.3 & 90.1 \\
\hline $\mathrm{M} / \mathrm{G}$ & 95.8 & 90.0 & 86.0 & 80.0 \\
\hline
\end{tabular}

大腿骨および脛骨コンポーネントの挿入角

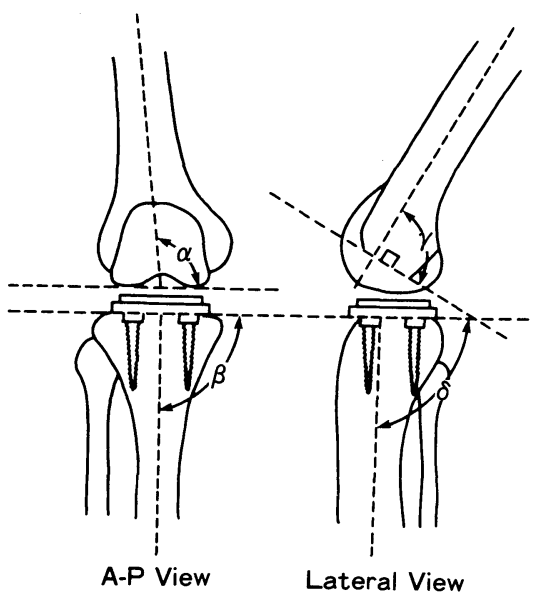

表 2 膝蓋の指標

\begin{tabular}{|c|c|c|}
\hline 外倒㣂位言 & $\begin{array}{c}\text { 0 20\% } \\
\text { 平均 } 2.5 \%\end{array}$ & $\begin{array}{c}20 \% \sim \\
\text { 平均 } 36.4 \%\end{array}$ \\
\hline Patellar Tilt & 平均 $3.6^{\circ}$ & 平均 $11.7^{\circ}$ \\
\hline & $\begin{array}{c}46 \text { 例 51関節 } \\
(89.5 \%)\end{array}$ & $\begin{array}{c}5 \text { 例 6関節 } \\
(10.5 \%)\end{array}$ \\
\hline
\end{tabular}

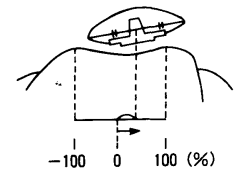

砠蓋骨の外側㣂位率(\%)

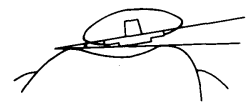

Patellar Tilt $\left({ }^{\circ}\right)$ 
及び入院後から術前までの約 1 ケ月間運動療法を行っ た後, さらに術後 1 ケ月，3 月月，6ケ月， 3 年と屈 曲拘縮角度を測定した。

RA とOA について比較すると， RA では手術前 の牽引や運動療法により, 術直前までに平均 $7.5^{\circ}$ 屈 曲角が改善しているのに対して, OA では, 平均 $2.5^{\circ}$ とほとんど変わっていない.しかし, 両者共に, 手術 により, RA 平均 $18.5^{\circ}, \mathrm{OA}$ 平均 $17.3^{\circ}$ 拘縮角が減 少している. 術後 3 ケ月までは, 徐々に屈曲角は改善 しているが， 3 ケ月以後は，6ケ月から 3 年に至るま で, 角度は変化していない。

\section{考察}

臨床評価では, 術後疼痛の改善が著しく, 術後平均 3 年 5 ケ月以上経過した時点においても, OA 及び RA 共に総合点で 80 点以上と高い成績を挙げている. これは，TKRによる安定した除痛の効果を示すもの であろう。

また，今回，Kinematic 型及び $\mathrm{M} / \mathrm{G}$ 型について コンポーネントの設置角を計測したが4)，概して良好 な設置が行われており，比較的良き臨床成績を得ら れた大切な要因であると考える。ささらにX線学的に Clear Zone を認めたものの, 明らかにコンポーネン トの緩みを疑わせる症例がほとんどなかったことも， それに依るものと思われる ${ }^{2}$. $30^{\circ}$ を超える重度屈曲 拘縮例については, 術前に牽引や十分な可動域訓練を
行うことにより，特にRA では，拘縮を或る程度改 善することが可能である(1)3). また術後 3 ケ月以後は 3 年まで可動域は, 安定して保たれており, 術前術後 早期の訓練が重要である.

ま と め

(1)当院で施行した TKR 50 例 57 関節につき術後成 績を評価しX線学的検討を加え報告した。

(2)X線学的に $2 \mathrm{~mm}$ を越える Clear Zoneはなく, 膝蓋骨コンポーネント設置不良例は 5 例 6 関節（10.5 \%)であった。

(3)重度の屈曲拘縮例では術前からの運動療法と安定 性を保持した適切な手術手技が重要であった。

(4)三大学試案による臨床評価では, OA, RA 共に ほほ満足すべき成績であった。

\section{文献}

1）山本純已他 : 関節リウマチ膝の屈曲拘縮の病態と治療 方について. 膝, $7: 178-181,1981$.

2）重野陽一他: Miller/Galante 人工膝関節の使用経験. 日関外誌, IX, (4), 593-602, 1990.

3）益川眞一他：RAにおけるセメントレス人工膝関節の 可動域. 九州リウマチ, $9: 190-195,1990$.

4) 小林千益他 : Total Condylar knee 人工膝関節とPorous Coated Aratomic (PCA) 人工膝関節の臨床的及び X線学的比較. 日関外誌， IX, (4), 609-617, 1990. 